\title{
THE FRESHWATER INVERTEBRATE FAUNA OF THE LAKE MESTON AREA
}

\author{
by A. M. M. Richardson and R. Swain
}

(with three tables, four text-figures and an appendix)

\begin{abstract}
RICHARDSON, A.M.M. \& SWAIN, R., $1989(31: x)$ : The freshwater invertebrates of the Lake Meston area. Pap. Proc. R. Soc. Tasm. 123: 275-286. https://doi.org/10.26749/rstpp.123.275 ISSN 0080-4703. Department of Zoology, University of Tasmania, GPO Box 252C, Hobart, Tasmania, Australia 7001.
\end{abstract}

Collections of littoral invertebrates were made from 21 freshwater bodies in the Lake Meston area of the western Central Plateau. Seventy-three taxa, including 42 identified as species, were collected. The fauna is similar to that found in other high-altitude lakes in Tasmania. A cluster analysis of sites by the presence or absence of species classified the standing waters into groups which could be explained by size and their species richness, apart from Lake Bill, probably the only lake of non-glacial origin, which did not associate with lakes of similar size. No correlations could be detected between the groupings and topographic descriptors of the lakes derived from maps. The named lakes in order of species richness were Meston (29 species), Adelaide \& Louisa (23), Poa (19), Myrtle (15), Bill (11) and Charles (7). Lake Meston is apparently the only lake in the area to support a substantial trout population.

Key Words: Central Plateau, Tasmania, invertebrates, lakes, streams, cluster analysis.

\section{INTRODUCTION}

Although Tasmania has a wealth of highland lakes there have been few studies of their invertebrate fauna, and those lakes that have been investigated have been the larger or more accessible systems. Perhaps because of the difficulty of obtaining consistent samples in the littoral zones of lakes (Leonard \& Timms 1974), the littoral fauna has been less studied than the benthos. Leonard \& Timms (1974) described the littoral rock fauna of Lakes Dove, Sorell and Crescent and suggested that the trophically poorer lakes were dominated by insects whereas the richer lakes were dominated by non-insects. Knott et al. (1978) examined the rock fauna in Hartz Lake, found that it was dominated by crustaceans, and suggested that this was related to the absence of trout from this lake, in contrast to those examined by Leonard \& Timms. The only other substantial studies of the invertebrates of Tasmanian lakes have been the benthic surveys of Timms (1978) and Fulton (1983a,b).

In February 1986 a survey of lakes in the northwestern part of the Central Plateau was organised by the Inland Fisheries Commission to investigate the potential of the unstocked lakes as trout fisheries. This provided the opportunity to sample and describe the invertebrate fauna of these lakes, and some neighbouring systems.
The survey included five of the larger and deeper lakes of this part of the Plateau: Lakes Meston, Adelaide, Louisa, Myrtle and Bill (fig. 1). The four largest lakes, Meston, Adelaide, Louisa and Myrtle, all appear to be of glacial origin (Derbyshire 1972, Derbyshire et al. 1965), while Lake Bill is not in a rock basin (Derbyshire et al. 1965) and may have arisen from the damming and subsequent redirection of Jacksons Creek, which drains Lake Myrtle into the Mersey River. The area also has a large number of smaller lakes and tarns.

Jurassic dolerite outcrops throughout the area, with accumulations of till in some valleys (Mines Department 1976). The vegetation varies with altitude and drainage; extensive stands of Nothofagus forest surround Lake Louisa and many of the other lakes, but most of the area is covered with open eucalypt forest on the thinner soils, or swamp and sedgeland where the drainage is poor. The higher ground of Mt Rogoona used to carry alpine dwarf forest, but this has been largely destroyed by recent fires.

Lake Meston was stocked with rainbow trout in the 1940's and the lake apparently maintains a substantial population of trout. The status of the other lakes is unclear. Lake Adelaide may once have been stocked, but no trout were found. The other three lakes do not appear to have trout populations at this time (French 1984). 


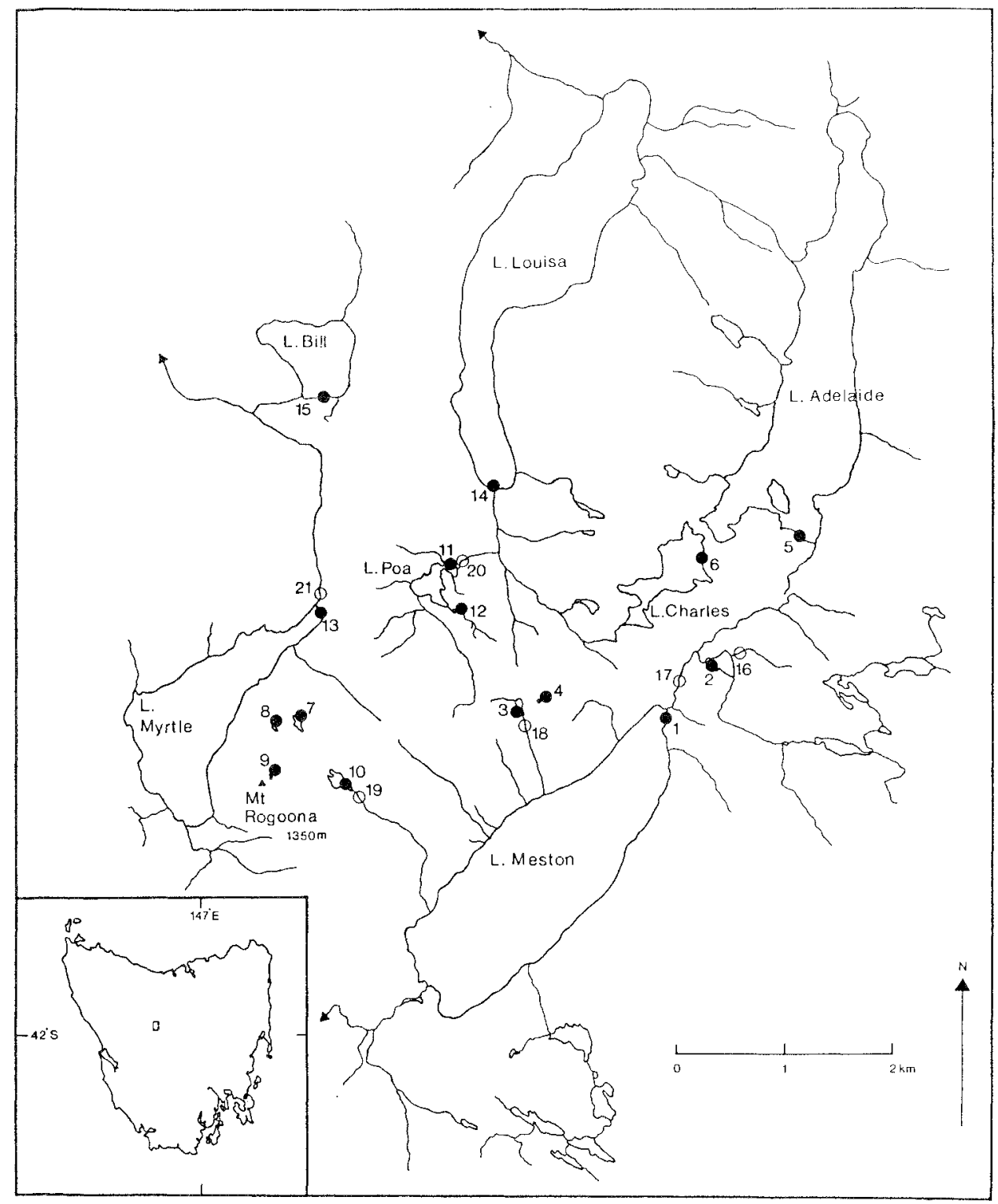

FIG. I - Outline map of the Lake Meston area, showing the major water bodies, streams and sampling localities (open circles represent collecting stations in streams, closed circles those in lakes, tarns and pools). 
No other published information is available on the limnology or biology of these lakes, though bathymetric surveys of Lakes Meston and Adelaide have been carried out (P.A. Tyler, pers. comm.).

\section{METHODS}

In February 1986, the five major lakes, plus a number of smaller lakes, tarns and streams were surveyed from a base camp at the eastern end of Lake Meston.

Collections were made at each locality by hand, i.e. picking animals from the surface of rocks and pieces of wood, and by Freshwater Biological Association hand nets in deeper water along soft banks and in weed beds. At each site collections were made from the full range of littoral habitats available.

At one or two localities burrows of freshwater crayfish were excavated with spades. From Lake Meston and Lake Louisa some material was collected from deeper water by SCUBA diving; tangle nets were used in Lake Meston to collect freshwater crayfish. Finally, flying insects were collected, using a light trap at Lake Meston and by means of hand nets elsewhere .

Apart from Lake Meston, most sites were only sampled on one occasion and no attempt was made to assess the abundance of the species collected.

No physical data were collected from the lakes in the field, but several parameters describing the standing water bodies were estimated from the 1:25 000 map of the area: the area in $\mathrm{km}^{2}$, the area of the catchment in $\mathrm{km}^{2}$, altitude $(\mathrm{m})$, length of shoreline $(\mathrm{km})$, maximum length $(\mathrm{km})$, maximum width $(\mathrm{km})$. From these, three more parameters were calculated: the ratio of catchment area to lake area (C/A), the mean width (area/maximum length) and the shoreline development (Bayly \& Williams 1973), i.e. the ratio of the shoreline length to the circumference of a circle with the same area, calculated as

$$
\frac{\mathrm{S}}{2 \sqrt{\pi \mathrm{A}}}
$$

where $\mathrm{S}=$ length of shoreline, $\mathrm{A}=$ lake area.

\section{RESULTS}

Figure 1 shows the locations of the 15 lentic and 6 lotic sites sampled. Other collecting sites, i.e. where crayfish burrows were excavated, are not marked.
Table 1 lists the taxa collected at each site, identified as far as published taxonomies allow. Groups for which the level of identification is particularly poor and where there are likely to have been several species present are the Trichoptera, Chironomidae and Oligochaeta.

In all, 73 taxa were identified, of which 42 were identified to species. The fauna was dominated by insects, especially the nymphs of stoneflies. Amongst the non-insect fauna were molluscs, Physastra gibbosa and, less commonly, Isidorella hainesii, and the very common small bivalve Pisidium casertanum. Oligochaetes and turbellarians occurred at many sites.

Crustaceans were represented by calanoid copepods, ostracods, cladocerans, amphipods, syncarids and decapods. Two species of crangonyctoid amphipod were present, one of which, identified from the keys in Williams \& Barnard (1988) as Neoniphargus alpinus, was widely distributed in still and running waters, while the other, $N$. ?fultoni, was only found in an alpine pool on Mt Rogoona. The other amphipods were an eusirid, Paracalliope sp. (Lake Louisa only), and the ceinid Austrochiltonia australis. The syncarid, Anaspides tasmaniae, was only found at two sites: a tarn on Mt Rogoona (site 7) and the Lake Meston inflow creek (site 17), where it was very localised. Two species of crayfish were present, Parastacoides tasmanicus tasmanicus, which was found in type 2 burrows (Horwitz \& Richardson 1986) at several localities, and Astacopsis franklinii, which was collected by diving and by tangle nets in Lake Meston, where specimens with a carapace length of more than $100 \mathrm{~mm}$ were obtained. One A. franklinii female was carrying newly-hatched young.

In order to form a classification of the water bodies studied, the data were subjected to a cluster analysis. Similarities between the sites were measured in terms of the presence and absence of species at each, using Euclidean distance (Clifford \& Stephenson 1975, Pielou 1984). The resulting matrix of dissimilarities was converted into clusters of sites using the group average (UPGMA) method (Sokal \& Sneath 1973, Clifford \& Stephenson 1975) and expressed as a dendrogram. Analyses were performed by the program BIO $\Sigma$ TAT II (Pimentel \& Smith 1985)

Since results of cluster analysis can be seriously biased by the presence of rare species, or the failure to collect them at some sites, the analysis was carried out on a reduced data set containing 18 species, selected because they occurred at at least three of the total number of sites examined and 
TABLE 1

Invertebrate taxa identified from collections made in Lake Meston area

\begin{tabular}{|c|c|c|c|c|c|c|c|c|c|c|c|c|c|c|c|c|c|c|c|c|c|}
\hline & \multicolumn{21}{|c|}{ Site number* } \\
\hline & 1 & 2 & 3 & 4 & 5 & 6 & 7 & 8 & 9 & 10 & 11 & 12 & 13 & 14 & 15 & 16 & 17 & 18 & 19 & 20 & 21 \\
\hline \multicolumn{22}{|l|}{ Platyhelminthes } \\
\hline $\begin{array}{l}\text { Turbellaria } \\
\text { Temnocephalida }\end{array}$ & 1 & 1 & 0 & 0 & 0 & 1 & 1 & 1 & 0 & 0 & 1 & 0 & 0 & 0 & 0 & 0 & 0 & 0 & 0 & 0 & 0 \\
\hline \multicolumn{22}{|l|}{ Annelida } \\
\hline Oligochaeta & 1 & 1 & 0 & 0 & 0 & 0 & 0 & 0 & 0 & 1 & 1 & 0 & 1 & 1 & 0 & 0 & 0 & 0 & 0 & 0 & 1 \\
\hline Hirudined & 0 & 0 & 0 & 0 & 0 & 0 & 0 & 0 & 0 & 0 & 0 & 0 & 0 & 1 & 0 & 0 & 0 & 0 & 0 & 0 & 0 \\
\hline $\begin{array}{l}\text { Mollusca } \\
\text { Gastropcda } \\
\text { Planorbidae }\end{array}$ & & & & & & & & & & & & & & & & & & & & & \\
\hline Physastra gibbosa & 1 & 1 & 0 & 0 & 1 & 1 & 0 & 0 & 0 & 0 & 1 & 0 & 1 & 1 & 0 & 0 & 0 & 0 & 0 & 0 & 0 \\
\hline $\begin{array}{l}\text { Isidorella hainesii } \\
\text { Bivalvia } \\
\text { Sphaeriidae }\end{array}$ & 0 & 1 & 0 & 0 & 0 & 0 & 0 & 0 & 0 & 0 & 0 & 0 & 0 & 1 & 0 & 0 & 0 & 0 & 0 & 0 & 0 \\
\hline Pisidium casertanum & 1 & 1 & 0 & 0 & 1 & 1 & 1 & 0 & 0 & 1 & 1 & 1 & 1 & 1 & 1 & 1 & 1 & 1 & 1 & 1 & 1 \\
\hline \multicolumn{21}{|l|}{ Crustacea } & Copepoda \\
\hline Calanoida & 0 & 1 & 0 & 0 & 0 & 0 & 0 & 0 & 1 & 0 & 0 & 1 & 0 & 0 & 0 & 0 & 0 & 0 & 0 & 0 & 0 \\
\hline Ostracoda & 0 & 0 & 0 & 0 & 0 & 0 & 0 & 0 & 0 & 0 & 1 & 0 & 0 & 0 & 0 & 0 & 0 & 0 & 0 & 0 & 0 \\
\hline Cladocera & 0 & 1 & 0 & 0 & 0 & 0 & 0 & 0 & 0 & 0 & 1 & 0 & 0 & 0 & 0 & 0 & 0 & 0 & 0 & 0 & 0 \\
\hline \multicolumn{22}{|l|}{ Malacostraca } \\
\hline $\begin{array}{l}\text { Anaspides tasmaniae } \\
\text { Amphipoda } \\
\text { Crangonyctoidea }\end{array}$ & 0 & 0 & 0 & 0 & 0 & 0 & 1 & 0 & 0 & 0 & 0 & 0 & 0 & 0 & 0 & 0 & 1 & 0 & 0 & 0 & 0 \\
\hline Neoniphargus alpinus & 1 & 0 & 1 & 1 & 1 & 0 & 0 & 0 & 1 & 1 & 0 & 1 & 0 & 1 & 0 & 0 & 0 & 0 & 0 & 0 & 0 \\
\hline $\begin{array}{l}\text { N. ?fultoni } \\
\text { Ceinidae }\end{array}$ & 0 & 0 & 0 & 0 & 0 & 0 & 0 & 0 & 1 & 0 & 0 & 0 & 0 & 0 & 0 & 0 & 0 & 0 & 0 & 0 & 0 \\
\hline $\begin{array}{l}\text { Austrochiltonia australis } \\
\text { Eusiridae }\end{array}$ & 0 & 0 & 0 & 1 & 1 & 0 & 0 & 0 & 0 & 0 & 0 & 0 & 0 & 0 & 0 & 0 & 0 & 1 & 0 & 0 & 0 \\
\hline $\begin{array}{l}\text { Paracalliope sp. } \\
\text { Astacura } \\
\text { Parastacidae } \\
\text { Astacopsis franklinii } \\
\text { Parastacoides t. tasmanic } \\
\text { Arachnida }\end{array}$ & 0 & 0 & 0 & 0 & 0 & 0 & 0 & 0 & 0 & 0 & 0 & 0 & 0 & 1 & 0 & 0 & 0 & 0 & 0 & 0 & 0 \\
\hline Hydracarina & 1 & 1 & 0 & 1 & 1 & 0 & 0 & 0 & 0 & 0 & 1 & 1 & 0 & 1 & 1 & 0 & 0 & 0 & 0 & 0 & 0 \\
\hline $\begin{array}{l}\text { Insecta } \\
\text { Ephemeroptera } \\
\text { Leptophlebiidae }\end{array}$ & & & & & & & & & & & & & & & & & & & & & \\
\hline Atalophlebioides sp. & 0 & 1 & 0 & 0 & 0 & 0 & 0 & 0 & 0 & 0 & 0 & 0 & 1 & 1 & 1 & 0 & 1 & 0 & 1 & 1 & 1 \\
\hline Atalophlebia sp. & 1 & 0 & 0 & 0 & 1 & 0 & 0 & 0 & 0 & 0 & 1 & 0 & 1 & 1 & 1 & 0 & 0 & 0 & 0 & 1 & 0 \\
\hline Atalonella sp. & 0 & 0 & 0 & 0 & 0 & 0 & 0 & 0 & 0 & 0 & 0 & 0 & 1 & 0 & 0 & 0 & 0 & 0 & 0 & 0 & 0 \\
\hline Siphlonuridae & & & & & & & & & & & & & & & & & & & & & \\
\hline $\begin{array}{l}\text { Tasmanophlebia sp. } \\
\text { Plecoptera } \\
\text { Eustheniidae }\end{array}$ & 1 & 1 & 1 & 0 & 0 & 0 & 0 & 0 & 0 & 0 & 1 & 0 & 0 & 0 & 0 & 0 & 0 & 0 & 0 & 0 & 0 \\
\hline Eusthenia spectabilis & 1 & 0 & 1 & 0 & l & 1 & 0 & 0 & 0 & 0 & 0 & 0 & 1 & 1 & 0 & 0 & 1 & 0 & 1 & 0 & 0 \\
\hline E. costalis & 0 & 0 & 0 & 0 & 0 & 0 & 0 & 0 & 0 & 0 & 0 & 0 & 0 & 0 & 0 & 0 & 1 & 0 & 0 & 0 & 0 \\
\hline Notonemouridae & & & & & & & & & & & & & & & & & & & & & \\
\hline Austrocerca rieki & 1 & 1 & 1 & 0 & 1 & 0 & 0 & 0 & 0 & 0 & 0 & 1 & 1 & 0 & 0 & 1 & 0 & 0 & 0 & 0 & 1 \\
\hline A. tasmanica & 0 & 0 & 1 & 0 & 0 & 0 & 1 & 1 & 1 & 1 & 0 & 0 & 0 & 0 & 1 & 0 & 0 & 0 & 0 & 0 & 0 \\
\hline Austrocercella christinae & 0 & 0 & 0 & 0 & 1 & 0 & 0 & 0 & 0 & 0 & 0 & 0 & 0 & 0 & 0 & 0 & 0 & 0 & 0 & 0 & 0 \\
\hline Austrocercoides zwicki & 1 & 0 & 1 & 0 & 1 & 0 & 0 & 0 & 0 & 0 & 0 & 0 & 0 & 0 & 0 & 0 & 0 & 1 & 0 & 0 & 0 \\
\hline A. sp. & 0 & 1 & 0 & 0 & 0 & 0 & 0 & 0 & 0 & 0 & 1 & 0 & 0 & 0 & 0 & 0 & 0 & 1 & 1 & 0 & 0 \\
\hline Notonemoura lynchi & 1 & 0 & 0 & 0 & 0 & 1 & 0 & 0 & 0 & 0 & 0 & 0 & 0 & 1 & 0 & 0 & 0 & 0 & 0 & 0 & 0 \\
\hline
\end{tabular}


Site number*

$\begin{array}{lllllllllllllllllllll}1 & 2 & 3 & 4 & 5 & 6 & 7 & 8 & 9 & 10 & 11 & 12 & 13 & 14 & 15 & 16 & 17 & 18 & 19 & 20 & 21\end{array}$

\begin{tabular}{|c|c|c|c|c|c|c|c|c|c|c|c|c|c|c|c|c|c|c|c|c|c|}
\hline \multicolumn{22}{|l|}{ Gripopterygidae } \\
\hline Leptoperla varia & 1 & 1 & 0 & 0 & 1 & 1 & 1 & 0 & 0 & 0 & 1 & 0 & 1 & 1 & 1 & 0 & 0 & 0 & 0 & 0 & 0 \\
\hline L. beroe & 1 & 1 & 0 & 1 & 0 & 0 & 0 & 0 & 0 & 0 & $i$ & 0 & 0 & 0 & 0 & 1 & 0 & 1 & 0 & 0 & 0 \\
\hline \multicolumn{22}{|l|}{ Cardioperla varia } \\
\hline C. incerta & 1 & 0 & 0 & 0 & 0 & 0 & 0 & 0 & 0 & 0 & 0 & 0 & 0 & 0 & 0 & 0 & 1 & 0 & 0 & 0 & 0 \\
\hline C. sp. & 0 & 0 & 0 & 0 & 0 & 0 & 1 & 0 & 0 & 0 & 0 & 0 & 0 & 0 & 0 & 0 & 0 & 0 & 0 & 0 & 0 \\
\hline Dinotoperla serricauda & 1 & 0 & 0 & 0 & 0 & 0 & 0 & 0 & 0 & 0 & 0 & 0 & 0 & 0 & 0 & 0 & 0 & 0 & 0 & 0 & 0 \\
\hline Riekoperla sp. & 1 & 0 & 0 & 0 & 0 & 0 & 0 & 0 & 0 & 0 & 0 & 0 & 0 & 0 & 0 & 0 & 0 & 0 & 0 & 0 & 0 \\
\hline Neboissoperla sp. & 0 & 0 & 0 & 0 & 0 & 0 & 1 & 0 & 0 & 0 & 0 & 0 & 0 & 0 & 0 & 0 & 0 & 0 & 0 & 0 & 0 \\
\hline \multicolumn{22}{|l|}{ Odonata: Anisoptera } \\
\hline \multicolumn{22}{|l|}{ Aeschnidae } \\
\hline Austroaeschna hardyi & 0 & 0 & 0 & 0 & 0 & 0 & 0 & 0 & 0 & 0 & 1 & 0 & 0 & 1 & 0 & 0 & 0 & 0 & 0 & 0 & 0 \\
\hline \multicolumn{22}{|l|}{ Synthemidae } \\
\hline Synthemis tasmanica & 0 & 1 & 0 & 0 & 1 & 0 & 0 & 0 & 0 & 0 & 0 & 0 & 0 & 0 & 0 & 0 & 0 & 0 & 0 & 0 & 0 \\
\hline \multicolumn{22}{|l|}{ Zygoptera } \\
\hline \multicolumn{22}{|l|}{ Lestidae } \\
\hline Austrolestes io & 0 & 1 & 0 & 0 & 1 & 0 & 0 & 0 & 0 & 0 & 1 & 0 & 0 & 0 & 0 & 0 & 0 & 0 & 0 & 0 & 0 \\
\hline A. annulosus/psyche & 0 & 0 & 0 & 1 & 1 & 0 & 0 & 0 & 0 & 0 & 0 & 1 & 0 & 0 & 0 & 0 & 0 & 0 & 0 & 0 & 0 \\
\hline A. cingulatus & 0 & 0 & 0 & 0 & 1 & 0 & 0 & 0 & 0 & 0 & 0 & 0 & 0 & 0 & 0 & 0 & 0 & 0 & 0 & 0 & 0 \\
\hline \multicolumn{22}{|l|}{ Hemiptera } \\
\hline \multicolumn{22}{|l|}{ Corixidae } \\
\hline Sigara sp.1 & 0 & 0 & 0 & 0 & 0 & 0 & 0 & 0 & 0 & 0 & 0 & 0 & 0 & 0 & 0 & 0 & 0 & 1 & 0 & 0 & 0 \\
\hline S. sp. 2 & 0 & 0 & 0 & 1 & 0 & 0 & 0 & 0 & 1 & 0 & 0 & 1 & 0 & 0 & 0 & 0 & 0 & 0 & 0 & 0 & 0 \\
\hline \multicolumn{22}{|l|}{ Notonectidae } \\
\hline Anisops sp. & 0 & 0 & 0 & 1 & 0 & 0 & 0 & 0 & 0 & 0 & 0 & 0 & 0 & 0 & 0 & 0 & 0 & 0 & 0 & 0 & 0 \\
\hline Anisops? & 0 & 0 & 0 & 1 & 0 & 0 & 0 & 0 & 0 & 0 & 0 & 0 & 0 & 0 & 0 & 0 & 0 & 0 & 0 & 0 & 0 \\
\hline Naucoridae & & & & & & & & & & & & & & & & & & & & & \\
\hline Naucoris congrex & 0 & 0 & 0 & 0 & 0 & 0 & 0 & 0 & 0 & 0 & 1 & 0 & 0 & 0 & 0 & 0 & 0 & 0 & 0 & 0 & 0 \\
\hline Coleoptera & & & & & & & & & & & & & & & & & & & & & \\
\hline Psephenidae & & & & & & & & & & & & & & & & & & & & & \\
\hline Sclerocyphon lacustris & 1 & 0 & 0 & 0 & 0 & 0 & 0 & 0 & 0 & 0 & 0 & 0 & 1 & 0 & 0 & 0 & 0 & 0 & 0 & 0 & 0 \\
\hline S. secretus & 0 & 0 & 0 & 0 & 0 & 0 & 0 & 0 & 0 & 0 & 0 & 0 & 0 & 1 & 0 & 0 & 1 & 0 & 0 & 0 & 0 \\
\hline Helodidae & 1 & 0 & 0 & 0 & 0 & 0 & 0 & 0 & 0 & 0 & 0 & 0 & 0 & 1 & 0 & 0 & 0 & 0 & 0 & 0 & 0 \\
\hline Helminthidae & 0 & 0 & 0 & 0 & 0 & 0 & 0 & 0 & 0 & 0 & 0 & 0 & 0 & 0 & 1 & 0 & 0 & 0 & 0 & 0 & 0 \\
\hline Dytiscidae & 0 & 1 & 0 & 1 & 1 & 0 & 1 & 1 & 1 & 1 & 1 & 1 & 0 & 1 & 0 & 1 & 0 & 1 & 0 & 0 & 0 \\
\hline Gyrinidae & 0 & 0 & 0 & 1 & 0 & 0 & 0 & 0 & 0 & 0 & 0 & 0 & 0 & 0 & 0 & 0 & 0 & 0 & 0 & 0 & 0 \\
\hline Diptera & & & & & & & & & & & & & & & & & & & & & \\
\hline Chironomidae & 1 & 1 & 1 & 1 & 1 & 1 & 1 & 1 & 1 & 1 & 1 & 1 & 1 & 1 & 0 & 0 & 1 & 1 & 1 & 0 & 1 \\
\hline Simuliidae & 0 & 0 & 0 & 0 & 0 & 0 & 0 & 0 & 0 & 0 & 0 & 0 & 0 & 0 & 0 & 0 & 0 & 0 & 0 & 1 & 0 \\
\hline Trichoptera & & & & & & & & & & & & & & & & & & & & & \\
\hline Hydrobiosidae & 1 & 0 & 0 & 0 & 0 & 0 & 0 & 0 & 0 & 0 & 0 & 0 & 0 & 0 & 0 & 0 & 1 & 0 & 0 & 0 & 0 \\
\hline Hydroptilidae & 0 & 0 & 0 & 0 & 0 & 0 & 1 & 0 & 0 & 0 & 0 & 0 & 0 & 0 & 0 & 0 & 0 & 0 & 0 & 0 & 0 \\
\hline Ecnomidae & 0 & 0 & 0 & 0 & 1 & 0 & 0 & 0 & 0 & 0 & 0 & 0 & 0 & 1 & 1 & 0 & 0 & 0 & 0 & 0 & 0 \\
\hline Polycentropidae & 0 & 0 & 0 & 0 & 0 & 0 & 0 & 0 & 0 & 0 & 0 & 0 & 0 & 0 & 0 & 0 & 0 & 0 & 1 & 0 & 0 \\
\hline Limnephilidae & 0 & 0 & 0 & 0 & 1 & 0 & 1 & 1 & 1 & 1 & 1 & 0 & 1 & 1 & 1 & 0 & 0 & 0 & 0 & 0 & 0 \\
\hline Kokiriidae & 1 & 0 & 0 & 0 & 0 & 0 & 0 & 0 & 0 & 0 & 0 & 0 & 0 & 0 & 0 & 0 & 0 & 0 & 0 & 0 & 0 \\
\hline Tasimiidae & 0 & 0 & 0 & 0 & 0 & 0 & 0 & 0 & 0 & 1 & 0 & 0 & 0 & 0 & 1 & 0 & 0 & 0 & 0 & 0 & 0 \\
\hline Hydropsychidae & 1 & 0 & 0 & 0 & 0 & 0 & 0 & 0 & 0 & 0 & 0 & 0 & 1 & 0 & 0 & 0 & 0 & 0 & 0 & 0 & 0 \\
\hline Calocidae & 1 & 0 & 0 & 0 & 0 & 0 & 0 & 0 & 0 & 0 & 0 & 0 & 0 & 0 & 0 & 0 & 0 & 0 & 0 & 0 & 0 \\
\hline Helicophidae & 1 & 0 & 0 & 0 & 1 & 0 & 0 & 0 & 0 & 0 & 0 & 0 & 0 & 0 & 0 & 0 & 0 & 0 & 0 & 0 & 0 \\
\hline Atriplectidae & 1 & 0 & 0 & 0 & 1 & 0 & 1 & 0 & 0 & 0 & 0 & 0 & 0 & 1 & 0 & 0 & 0 & 0 & 0 & 0 & 1 \\
\hline Calamoceratidae & 0 & 0 & 0 & 0 & 0 & 0 & 0 & 0 & 0 & 0 & 0 & 1 & 0 & 0 & 0 & 0 & 0 & 0 & 0 & 0 & 0 \\
\hline Philoreithridae & 1 & 1 & 1 & 0 & 1 & 0 & 1 & 0 & 0 & 0 & 0 & 0 & 1 & 1 & 1 & 0 & 0 & 0 & 0 & 0 & 1 \\
\hline Leptoceridae & 0 & 1 & 1 & 1 & 1 & 0 & 1 & 1 & 1 & 0 & 1 & 1 & 0 & 0 & 1 & 0 & 0 & 1 & 0 & 0 & 1 \\
\hline Odontoceridae & 0 & 1 & 0 & 0 & 0 & 0 & 1 & 0 & 0 & 0 & 0 & 0 & 0 & 1 & 0 & 0 & 1 & 0 & 0 & 0 & 0 \\
\hline Helicopsychidae & 1 & 0 & 0 & 0 & 0 & 0 & 0 & 0 & 0 & 0 & 0 & 0 & 0 & 0 & 0 & 0 & 0 & 0 & 0 & 0 & 0 \\
\hline
\end{tabular}

* The 21 collecting sites are shown in figure 1 . 

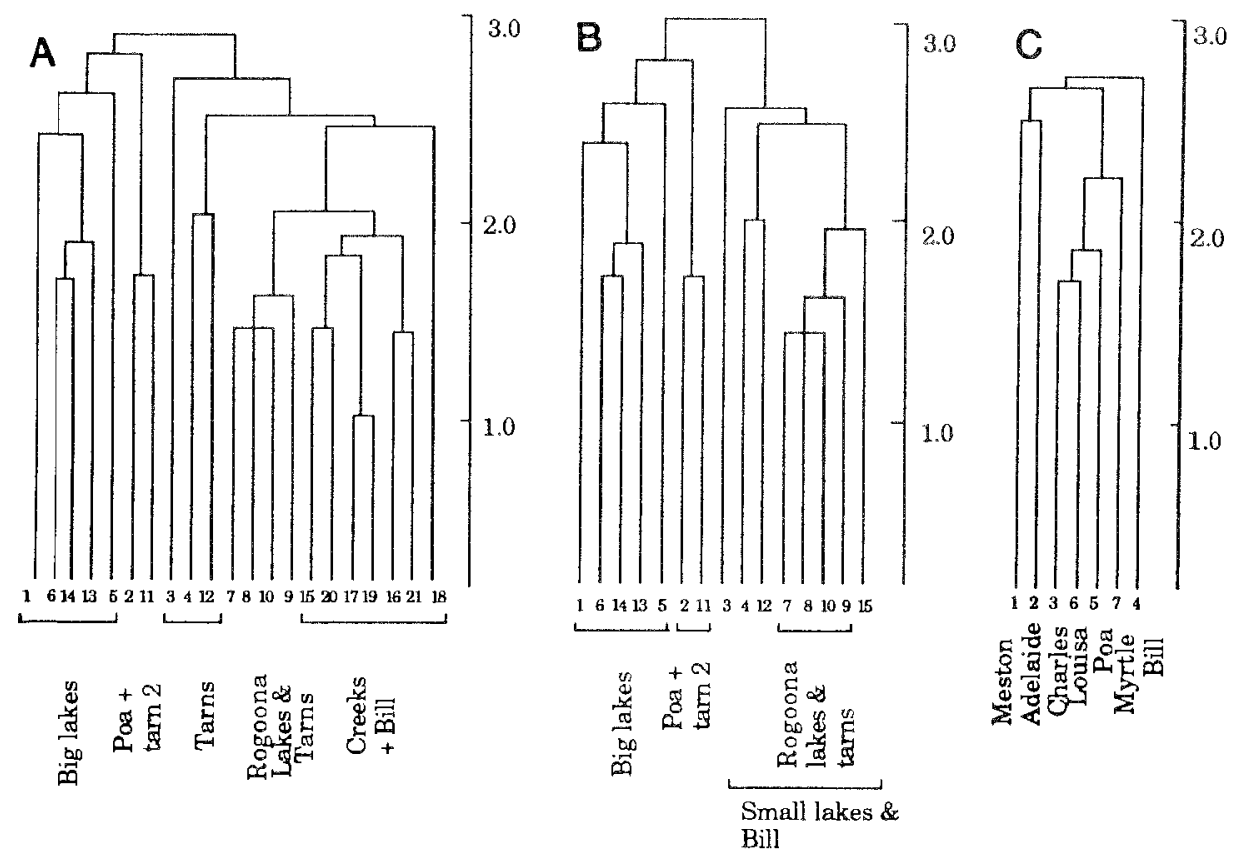

FIG. 2 - Dendrograms resulting from cluster analyses of the collecting stations by species (dissimilarity measure: Euclidean distance, clustering strategy: UPGMA). (a) all sites, (b) lentic sites only, (c) large lakes only. Site numbers refer to the localities in figure 1 , apart from dendrogram $(c)$ where the numbers refer to lakes as follows. I, Lake Meston; 2, Lake Adelaide; 3, Lake Charles; 4, Lake Bill; 5, Lake Poa; 6, Lake Louisa; 7, Lake Myrtle. The vertical scale is dissimilarity measured as Euclidean distance.

could be identified to at least generic level. The occurrences of all species and the selected species set are presented in the appendix. Three groups of sites were analysed separately: the complete set (21 sites), the lentic sites alone (15 sites) and the named lakes alone ( 7 sites). The resulting dendrograms are shown in figure 2.

Analysis of all sites (fig. 2A) shows a basic division of the sites into the large lakes, plus Lake Poa and Site 2, against the smaller lakes and tarns, plus all the lotic sites. Lake Bill is included in the second group. This division is based partly on species richness, the second group of sites having lower numbers of species, but there is also one absolute difference in the fauna: the presence of the snail Physastra gibbosa at all the sites in the first group and none in the second. No other absolute differences appear, but the stonefly Leptoperla varia is present at all the sites in the first group but only two out of the 14 in the second group.

Within the second group, subdivisions also correlate with species richness. The Rogoona lakes and tarns are depauperate and have little that characterises them, apart from the absence of species and the presence of Austrocerca tasmanica which they share with only Site 3 and Lake Bill. The creeks and Lake Bill form an indistinct group.

When the lotic sites are excluded from the analysis (fig. 2B), the pattern remains similar to that in the previous analysis. The initial division is into the larger lakes versus the tarns and Lake Bill, and is based on species number and the presence of Physastra gibbosa, Leptoperla varia, Atalophlebia sp. and Eusthenia spectabilis, and the absence of Austrocerca tasmanica and Sigara sp. 2, in the lakes. Within the "big" lake group, Lake Poa and Site 2 are separated from the bigger lakes by the presence of Tasmanophlebia sp., Austrocercoides sp., Austrolestes io, and the absence of Eusthenia spectabilis.

In the "small" lake group the only recognisable subgroup is the Rogoona lakes, characterised, as mentioned above, only by their species poorness.

The final analysis is of the named (i.e. "big") lakes only (fig. 2C). Not surprisingly, in view of the relationships described above, Lake Bill separates from all other lakes. This is based principally on the absence of species (e.g. Physastra 
gibbosa, which was present in all the other lakes), but also on the presence of Austrocerca tasmanica. The other principal division is between Lakes Meston and Adelaide and the remaining lakes. These two large lakes have the most species recorded and share Austrocercoides zwicki to the exclusion of all the others. Austrocerca rieki is only found in Meston, Adelaide and Myrtle within this group.

Summarising the significant points from this analysis, there appear to be at least three groupings within the standing waters samples, which correlate basically with size: the mountain tarns (c, $<2$ ha.), which are species poor but possess Austrocerca tasmanica, the medium-sized lakes (Lake Poa, Sites $2 \& 3$ ), which are intermediate in species richness and not characterised by the exclusive possession of any species, and the large lakes (Meston, Adelaide, Myrtle, Louisa, Charles), which are richest in species and best characterised by Physastra gibbosa, Leptoperla varia and Eusthenia spectabilis. Lake Bill does not fit with any of these groups, except the mountain tarns.
To provide some environmental basis for the classification, the lentic water bodies were subjected to a cluster analysis on the basis of the topographic parameters taken from the 1:25000 map (table 2). Each parameter was transformed to its $z$-value to prevent the numerically large items from dominating the rest (Clifford \& Stephenson 1975). The resulting dendrograms are presented in figure 3.

The analysis is apparently most strongly influenced by the catchment/area ratio, since lakes 2 and 3 , with the two highest C/A's, split off early from the rest. Within the remaining group the four largest lakes group together, as do the smallest (sites $4,8,9 \& 12$ ). These groupings, although they can be related quite easily to the topography of the lakes and their catchments, do not bear any close resemblance to the groupings based on the fauna.

The named lakes can be ranked on the basis of species richness. In order of declining richness, the ranking is: Meston (29), Adelaide \& Louisa (23 each), Poa (19), Myrtle (15), Bill (11) and Charles (7). Once again, Lake Meston stands out but,

\section{TABLE 2}

Topographical characteristics of the lentic water bodies of the Lake Meston area, derived from the 1:25 000 map

\begin{tabular}{|c|c|c|c|c|c|c|c|c|c|}
\hline $\begin{array}{l}\text { Site } \\
\text { No. }\end{array}$ & $\begin{array}{c}\text { Area } \\
\text { (A) } \\
\mathrm{km}^{2}\end{array}$ & $\begin{array}{c}\text { Catchment } \\
(\mathrm{C}) \\
\mathrm{km}^{2}\end{array}$ & $\mathrm{C} / \mathrm{A}$ & $\begin{array}{l}\text { Altitude } \\
\text { m }\end{array}$ & $\begin{array}{l}\text { Shore } \\
\text { length } \\
\text { km }\end{array}$ & $\begin{array}{c}\text { Shoreline } \\
\text { development* }\end{array}$ & $\begin{array}{c}\text { Max } \\
\text { length } \\
\text { km }\end{array}$ & $\begin{array}{c}\text { Mean } \\
\text { width } \\
\text { km }\end{array}$ & $\begin{array}{c}\text { Max } \\
\text { width } \\
\text { km }\end{array}$ \\
\hline 1 & 2.07 & 16.4 & 6.1 & 1018 & 19.8 & 3.4 & 3.4 & 0.79 & 1.1 \\
\hline 2 & 0.03 & 3.82 & 119.4 & 1040 & 1.7 & 2.7 & 0.3 & 0.11 & 0.25 \\
\hline 3 & 0.005 & 0.17 & 34.2 & 1100 & 0.3 & 1.2 & 0.15 & 0.03 & 0.05 \\
\hline 4 & 0.003 & 0.005 & 1.7 & 1160 & 0.2 & 1.0 & 0.03 & 0.10 & 0.03 \\
\hline 5 & 2.34 & 8.7 & 3.7 & 1055 & 24.8 & 4.6 & 4.1 & 0.57 & 0.88 \\
\hline 6 & 0.28 & 0.86 & 3.1 & 1060 & 9.6 & 5.2 & 1.1 & 0.25 & 0.50 \\
\hline 7 & 0.006 & 0.12 & 19.5 & 1250 & 0.8 & 2.9 & 0.18 & 0.03 & 0.05 \\
\hline 8 & 0.001 & 0.002 & 2.0 & 1340 & 0.1 & 1.0 & 0.01 & 0.10 & 0.01 \\
\hline 9 & 0.001 & 0.002 & 2.0 & 1340 & 0.1 & 1.0 & 0.01 & 0.10 & 0.01 \\
\hline 10 & 0.022 & 0.26 & 11.8 & 1260 & 1.6 & 3.0 & 0.28 & 0.08 & 0.13 \\
\hline 11 & 0.079 & 1.84 & 23.3 & 1030 & 3.6 & 3.6 & 0.5 & 0.16 & 0.25 \\
\hline 12 & 0.001 & 0.002 & 2.0 & 1030 & 0.1 & 1.0 & 0.01 & 0.10 & 0.01 \\
\hline 13 & 1.25 & 4.9 & 4.0 & 1207 & 16.3 & 4.1 & 2.4 & 0.52 & 0.88 \\
\hline 14 & 2.29 & 24.1 & 10.5 & 847 & 23.7 & 4.4 & 4.0 & 0.57 & 1.0 \\
\hline 15 & 0.44 & 2.9 & 6.8 & 951 & 6.7 & 2.9 & 1.0 & 0.43 & 0.75 \\
\hline
\end{tabular}

\footnotetext{
* as defined in text (p.277)
} 
compared to the cluster analysis, Lake Poa changes its position relative to Lakes Myrtle and Bill.

Table 3 shows correlations between species richness in each of the standing water bodies and the topographic parameters. There are significant relationships between species richness and six of the nine parameters (area, catchment area, shoreline length, maximum length, mean width and maximum width); however, all of these correlate strongly with lake area. Figure 4 shows that there is a weak relationship between species richness and lake area; the greatest deviations from the relationship are for Lake Charles (lower species richness than expected), Lake Meston and "Meston 1" tarn (higher species richness than expected). Including further topographic variables in a multiple regression improves the strength of the relationship dramatically, but further analysis is probably not helpful because of the strong relationships between most of the topographical parameters and lake size; those parameters which are not strongly correlated with lake size (catchment/area, shoreline development and altitude) do not correlate significantly with species richness. While supporting the general relationship between lake area and species richness, this analysis does not explain the exceptional position of Lake Bill in all the cluster analyses.

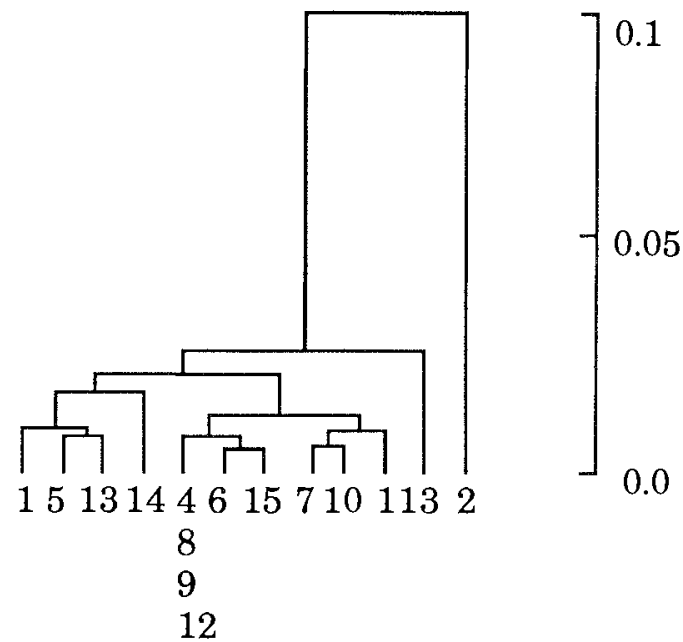

FIG. 3 - Dendrogram resulting from cluster analyses of the lentic collecting stations by topographical parameters (dissimilarity measure: Euclidean distance, clustering strategy: UPGMA), based on nine parameters (lake area, catchment area, $C / A$, altitude, perimeter length, shoreline development, maximum length, mean width, maximum width). The site numbers refer to the localities in figure 1 . The vertical scale is dissimilarity measured as Euclidean distance.

\section{TABLE 3}

Correlation coefficients (Pearson's product moment coefficient) between species number in all standing water bodies and the physical parameters derived from the topographic map (table 2)**

\begin{tabular}{|c|c|c|c|c|c|c|c|c|c|c|}
\hline & $\begin{array}{l}\text { Spp. } \\
\text { no. }\end{array}$ & Area & $\begin{array}{c}\text { Catchment } \\
\text { area }\end{array}$ & C/A & Altitude & $\begin{array}{l}\text { Shore } \\
\text { length }\end{array}$ & $\begin{array}{c}\text { Shoreline } \\
\text { development }\end{array}$ & $\begin{array}{l}\text { Max. } \\
\text { length }\end{array}$ & $\begin{array}{l}\text { Mean } \\
\text { width }\end{array}$ & $\begin{array}{l}\text { Max. } \\
\text { width }\end{array}$ \\
\hline Spp. No. & 1.000 & 0.739 & 0.767 & 0.265 & -0.585 & 0.683 & 0.465 & 0.724 & 0.688 & 0.670 \\
\hline Area & 0.73 & 1.000 & 0.881 & -0.227 & -0.498 & 0.978 & 0.617 & 0.993 & 0.921 & 0.900 \\
\hline Catch. area & 0.767 & 0.881 & 1.000 & -0.044 & -0.626 & 0.836 & 0.508 & 0.867 & 0.804 & 0.803 \\
\hline $\mathrm{C} / \mathrm{A}$ & 0.265 & -0.227 & -0.044 & 1.000 & -0.171 & -0.230 & -0.028 & -0.210 & -0.261 & -0.160 \\
\hline Altitude & -0.585 & -0.498 & -0.626 & -0.171 & 1.000 & -0.524 & -0.464 & -0.527 & -0.521 & -0.595 \\
\hline Shore length & 0.683 & 0.978 & 0.836 & -0.230 & -0.524 & 1.000 & 0.748 & 0.995 & 0.924 & 0.935 \\
\hline Shore dev. & 0.465 & 0.617 & 0.508 & -0.028 & -0.464 & 0.748 & 1.000 & 0.700 & 0.618 & 0.742 \\
\hline Max. length & 0.724 & 0.993 & 0.867 & -0.210 & -0.527 & 0.995 & 0.700 & 1.000 & 0.921 & 0.923 \\
\hline Mean width & 0.688 & 0.921 & 0.804 & -0.261 & -0.521 & 0.924 & 0.618 & 0.921 & 1.000 & 0.973 \\
\hline Max. width & 0.670 & 0.900 & 0.803 & -0.160 & -0.595 & 0.935 & 0.742 & 0.923 & 0.973 & 1.000 \\
\hline
\end{tabular}

* Critical value for coefficient at 0.01 level of probability $=0.641$. 


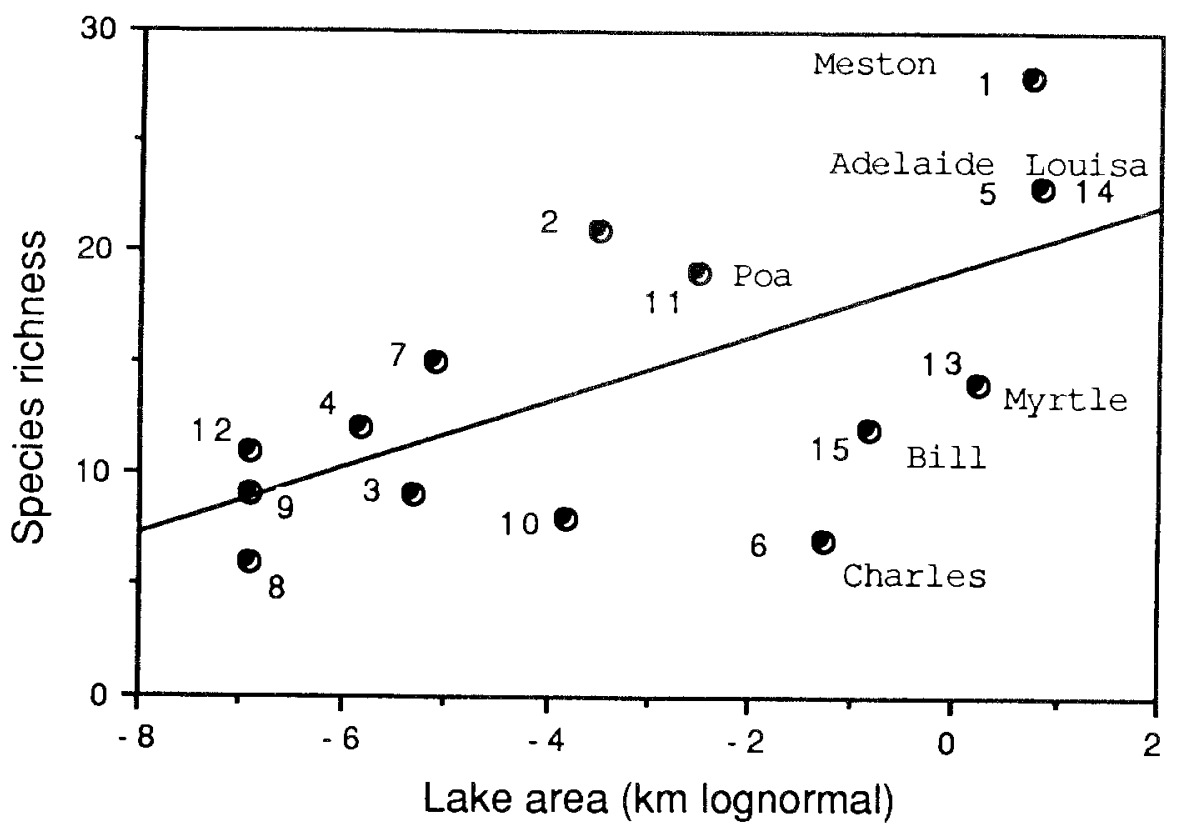

FIG. 4 - The relationship between the number of species collected in the lentic habitats and the area of the water bodies. The numbers refer to the localities in figure 1. The line gives the least squares regression $\left(Y=19.036+1.481 X ; r^{2}=0.428\right)$.

\section{DISCUSSION}

Low levels of identification make it hard to compare the fauna in the Meston lakes and those previously examined, i.e. Dove Lake, Lakes Sorell and Crescent (Leonard \& Timms 1974) and Hartz Lake (Knott et al. 1978). Not surprisingly, the littoral fauna of the Meston lakes appears to relate more closely to that of Dove and Hartz Lakes than the lower altitude lakes of Sorell and Crescent. The latter lakes have a better developed molluscan fauna, more turbellarians and their crustacean fauna includes representatives of two groups not found in the highland lakes: the janirid isopods (Heterias petrensis) and the atyid shrimps (Paratya australiensis). Anaspides tasmaniae is absent from the lowland lakes, but present in the Meston area, and Hartz Lake.

Within the Meston area, it is clear that Lake Meston stands apart from the other lakes both in terms of species richness and in the occurrence of unique taxa (the gripopterygid stoneflies Dinotoperla serricauda and Riekoperla sp. and the caddisfly familes Kokiriidae and Helicopsychidae).
It is interesting that this lake carries a thriving trout population, while the others support very low or no populations at present. The success of the trout in Lake Meston may be related to the invertebrate faunal richness. There is apparently nothing in the physical size or setting of Lake Meston which might explain the difference. Other factors which might be important, but about which there is no information, are the overall level of productivity, the quality of the surrounding catchments and the exposure of the lakes to wind and wave action.

Leonard \& Timms (1974) point out the high variability between samples from the littoral zone in lakes and suggest a number of factors which contribute to this variability. In this study the factor most likely to cause bias in our comparisons is the position of collecting stations in the lakes. Most lakes were sampled at only one general locality (although several samples were collected in that area to allow for local variation) because of the size of the lakes and the restricted access. Because of the configuration of the lakes, Meston and Myrtle were sampled on shores exposed to the prevailing wind, while relatively sheltered shores 
were sampled at Lakes Adelaide and Louisa.

A general relationship between lake area and species richness is to be expected from ecological theory (Macarthur \& Wilson 1967), but the area available to the littoral fauna is not related to lake area in a simple way, and other factors such as catchment quality, substrate type and productivity will control the number of species present. Lake Bill, which has an exceptional fauna, appears to have had a different origin to the other large lakes. Lakes Meston, Adelaide, Myrtle and Louisa appear to be glacial features, and Poa and Charles are probably kettle lakes with rocky bottoms and shores; but Lake Bill is shallow with an organic bottom and peaty shores (Derbyshire et al. 1965), apparently formed from the damming of a small creek. The differences in substrate, and probably in water quality, are sufficient to explain the exceptional fauna in Lake Bill.

\section{ACKNOWLEDGEMENTS}

We wish to thank the Inland Fisheries Commission of Tasmania for providing helicopter transport into the area and assisting with collecting. We also thank Laurie Cook, Ivor Growns, Richard Holmes, Ron Mawbey and Adam Smolenski for assisting in the collecting and with the identifications. Wayne Fulton made helpful comments on an earlier draft of the MS.

\section{REFERENCES}

BAYLY, I.A.E \& WIELIAMS, W.D., 1973: INLAND WATERS AND THEIR ECOLOGY. LOngman, Melbourne.

Clifford, H.T. \& Stephenson, W., 1975: AN INTRODUCTION TO NUMERICAL CLASSIFICATION. Academic Press, New York.

Derbyshire, E., 1972: Pleistocene glaciation of Tasmania: a review and speculations. Austr. Geogr. Stud. 10: 79-94.
Derbyshire, E., Banks, M.R., Davits, J.L. \& Jennings, J.N., 1965: A GLACIAL MAP OF TASMANIA. ROy. Soc. Tasm. Spec. Plibl. 2.

FrENCH, G., 1984: TASMANIAN TROUTING, WHERE AND HOW. Greg French, Orford, Tasmania.

Fulton, W., 1983a: Macrobenthic fauna of Great Lake, Arthurs Lake and Lake Sorell, Tasmania. Aust. J. Mar. Freshwater Res. 34: 775-785.

Fulton, W., 1983b: Qualitative and quantitative variation in the macrobenthic fauna of the orginal and new lake areas of Great Lake and Arthurs Lake, Tasmania. Aust. J. Mar. Freshw. Res. 34: 787-803.

Horwtrz, P.H.J. \& Richardson, A.M.M., 1986: An ecological classification of the burrows of Australian freshwater crayfish. Aust. J. Mar. Freshw. Res. 37: $237-242$.

Knott, B., Suter, P.J. \& Richardson, A.M.M., 1978: A preliminary observation on the littoral rock fauna of Hartz Lake and Hartz Creek, southern Tasmania, with notes on the water chemistry of some neighbouring lakes. Aust. J. Mar. Freshw. Res. 29: 703-715.

LEONARD, B.V. \& Timms, B.V., 1974: The littoral rock fauna of three highland lakes in Tasmania. Pap. Proc. R. Soc. Tasm. 108: 151-156.

Macarthur, R.H. \& WILSON, E.O., 1967: THE THEORY OF ISLAND BIOGEOGRAPHY. Princeton University Press, Princeton, N.J.

Mines Department of Tasmania, 1976: GEOLOGY OF TASMANIA, 1:500 000 MAP. Tasmanian Department of Mines, Hobart.

Pielou, E.C., 1984: THE INTERPRETATION OF ECOLOGICAL DATA. John Wiley, New York.

Pimentel, R.A. \& Smith, J.D., 1985: BIO乏TAT. Sigma Soft, Placentia, California.

SOKAL, R.R. \& SNEATH, P.H.A., 1963: PRINCIPLES OF NUMERICAL TAXONOMY. W.H. Freeman, San Francisco.

Timms, B.V., 1978: The benthos of seven lakes in Tasmania. Arch. Hydrobiol. 84: 422-444.

Williams, W.D. \& Barnard, J.L., 1988: The taxonomy of crangonyctoid Amphipoda (Crustacea) from Australian freshwaters: foundation studies. Rec. Aus. Mus., Suppl. 10:1-180.

(accepted 10 February 1989) 


\section{APIENDIX 1}

Occurrences of all recognised taxa in the 21 sites examined in the Lake Meston area

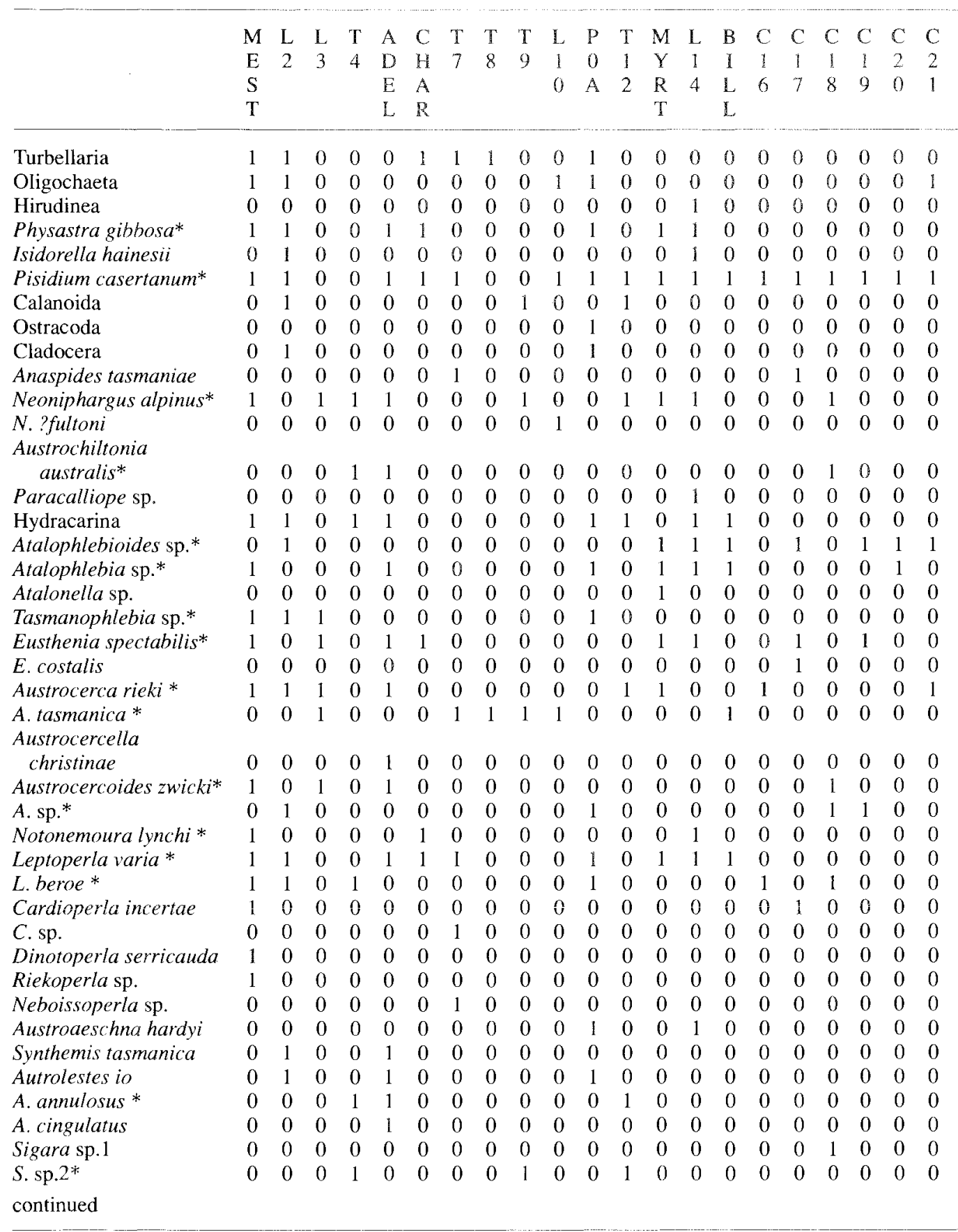




\begin{tabular}{|c|c|c|c|c|c|c|c|c|c|c|c|c|c|c|c|c|c|c|c|c|c|}
\hline & $\begin{array}{l}\mathrm{M} \\
\mathrm{E} \\
\mathrm{S} \\
\mathrm{T}\end{array}$ & $\begin{array}{l}\mathrm{L} \\
2\end{array}$ & $\begin{array}{l}\mathrm{L} \\
3\end{array}$ & $\begin{array}{l}\mathrm{T} \\
4\end{array}$ & $\begin{array}{l}\mathrm{A} \\
\mathrm{D} \\
\mathrm{E} \\
\mathrm{L}\end{array}$ & $\begin{array}{l}\mathrm{C} \\
\mathrm{H} \\
\mathrm{A} \\
\mathrm{R}\end{array}$ & $\begin{array}{l}T \\
7\end{array}$ & $\begin{array}{l}\mathrm{T} \\
8\end{array}$ & $\begin{array}{l}\mathrm{T} \\
9\end{array}$ & $\begin{array}{c}\mathrm{L} \\
1 \\
0\end{array}$ & $\begin{array}{l}\mathrm{P} \\
0 \\
\mathrm{~A}\end{array}$ & $\begin{array}{l}\mathrm{T} \\
1 \\
2\end{array}$ & $\begin{array}{l}\mathrm{M} \\
\mathrm{Y} \\
\mathrm{R} \\
\mathrm{T}\end{array}$ & $\begin{array}{l}\mathrm{L} \\
1 \\
4\end{array}$ & $\begin{array}{l}\text { B } \\
\text { I } \\
\text { L } \\
\text { L }\end{array}$ & $\begin{array}{l}\mathrm{C} \\
1 \\
6\end{array}$ & $\begin{array}{l}C \\
1 \\
7\end{array}$ & $\begin{array}{l}\mathrm{C} \\
1 \\
8\end{array}$ & $\begin{array}{l}\mathrm{C} \\
1 \\
9\end{array}$ & $\begin{array}{l}C \\
2 \\
0\end{array}$ & $\begin{array}{l}\mathrm{C} \\
2 \\
1\end{array}$ \\
\hline Anisops spl & 0 & 0 & 0 & 1 & 0 & 0 & 0 & 0 & 0 & 0 & 0 & 0 & 0 & 0 & 0 & 0 & 0 & 0 & 0 & 0 & 0 \\
\hline A. sp. 2 & 0 & 0 & 0 & 1 & 0 & 0 & 0 & 0 & 0 & 0 & 0 & 0 & 0 & 0 & 0 & 0 & 0 & 0 & 0 & 0 & 0 \\
\hline Naucoris congrex & 0 & 0 & 0 & 0 & 0 & 0 & 0 & 0 & 0 & 0 & 1 & 0 & 0 & 0 & 0 & 0 & 0 & 0 & 0 & 0 & 0 \\
\hline Sclerocyphon lacustris & 1 & 0 & 0 & 0 & 0 & 0 & 0 & 0 & 0 & 0 & 0 & 0 & 1 & 0 & 0 & 0 & 0 & 0 & 0 & 0 & 0 \\
\hline S. secretus & 0 & 0 & 0 & 0 & 0 & 0 & 0 & 0 & 0 & 0 & 0 & 0 & 0 & 1 & 0 & 0 & 1 & 0 & 0 & 0 & 0 \\
\hline Helodidae & 1 & 0 & 0 & 0 & 0 & 0 & 0 & 0 & 0 & 0 & 0 & 0 & 0 & 1 & 0 & 0 & 0 & 0 & 0 & 0 & 0 \\
\hline Helminthidae & 0 & 0 & 0 & 0 & 0 & 0 & 0 & 0 & 0 & 0 & 0 & 0 & 0 & 0 & 1 & 0 & 0 & 0 & 0 & 0 & 0 \\
\hline Dystiscidae & 0 & 1 & 0 & 1 & 1 & 0 & 1 & 1 & 1 & 1 & 1 & 1 & 0 & 1 & 0 & 1 & 0 & 1 & 0 & 0 & 0 \\
\hline Gyrinid ae & 0 & 0 & 0 & 1 & 0 & 0 & 0 & 0 & 0 & 0 & 0 & 0 & 0 & 0 & 0 & 0 & 0 & 0 & 0 & 0 & 0 \\
\hline Chironomidae & 1 & 1 & 1 & 1 & 1 & 1 & 1 & 1 & 1 & 1 & 1 & 1 & 1 & 1 & 0 & 0 & 1 & 1 & 1 & 0 & 1 \\
\hline Simulidae & 0 & 0 & 0 & 0 & 0 & 0 & 0 & 0 & 0 & 0 & 0 & 0 & 0 & 0 & 0 & 0 & 0 & 0 & 0 & 1 & 0 \\
\hline Hydrobiosidae & 1 & 0 & 0 & 0 & 0 & 0 & 0 & 0 & 0 & 0 & 0 & 0 & 0 & 0 & 0 & 0 & 1 & 0 & 0 & 0 & 0 \\
\hline Hydroptilidae & 0 & 0 & 0 & 0 & 0 & 0 & 1 & 0 & 0 & 0 & 0 & 0 & 0 & 0 & 0 & 0 & 0 & 0 & 0 & 0 & 0 \\
\hline Ecnomidae & 0 & 0 & 0 & 0 & 1 & 0 & 0 & 0 & 0 & 0 & 0 & 0 & 0 & 1 & 1 & 0 & 0 & 0 & 0 & 0 & 0 \\
\hline Polycentropidae & 0 & 0 & 0 & 0 & 0 & 0 & 0 & 0 & 0 & 0 & 0 & 0 & 0 & 0 & 0 & 0 & 0 & 0 & 1 & 0 & 0 \\
\hline Limnephilidae & 0 & 0 & 0 & 0 & 1 & 0 & 1 & 1 & 1 & 1 & 1 & 0 & 1 & 1 & 1 & 0 & 0 & 0 & 0 & 0 & 0 \\
\hline Kokiriidae & 1 & 0 & 0 & 0 & 0 & 0 & 0 & 0 & 0 & 0 & 0 & 0 & 0 & 0 & 0 & 0 & 0 & 0 & 0 & 0 & 0 \\
\hline Tasimiidae & 0 & 0 & 0 & 0 & 0 & 0 & 0 & 0 & 0 & 1 & 0 & 0 & 0 & 0 & 1 & 0 & 0 & 0 & 0 & 0 & 0 \\
\hline Hydropsychidae & 1 & 0 & 0 & 0 & 0 & 0 & 0 & 0 & 0 & 0 & 0 & 0 & 1 & 0 & 0 & 0 & 0 & 0 & 0 & 0 & 0 \\
\hline Calocidae & 1 & 0 & 0 & 0 & 0 & 0 & 0 & 0 & 0 & 0 & 0 & 0 & 0 & 0 & 0 & 0 & 0 & 0 & 0 & 0 & 0 \\
\hline Helicophidae & 1 & 0 & 0 & 0 & 1 & 0 & 0 & 0 & 0 & 0 & 0 & 0 & 0 & 0 & 0 & 0 & 0 & 0 & 0 & 0 & 0 \\
\hline Atriplectidae & 1 & 0 & 0 & 0 & 1 & 0 & 1 & 0 & 0 & 0 & 0 & 0 & 0 & 1 & 0 & 0 & 0 & 0 & 0 & 0 & 1 \\
\hline Calamoceratidae & 0 & 0 & 0 & 0 & 0 & 0 & 0 & 0 & 0 & 0 & 0 & 1 & 0 & 0 & 0 & 0 & 0 & 0 & 0 & 0 & 0 \\
\hline Philoreithridae & 1 & 1 & 1 & 0 & 1 & 0 & 1 & 0 & 0 & 0 & 0 & 0 & 1 & 1 & 1 & 0 & 0 & 0 & 0 & 0 & 1 \\
\hline Leptoceridae & 0 & 1 & 1 & 1 & 1 & 0 & 1 & 1 & 1 & 0 & 1 & 1 & 0 & 0 & 1 & 0 & 0 & 1 & 0 & 0 & 1 \\
\hline Odontoceridae & 0 & 1 & 0 & 0 & 0 & 0 & 1 & 0 & 0 & 0 & 0 & 0 & 0 & 1 & 0 & 0 & 1 & 0 & 0 & 0 & 0 \\
\hline Helicopsychidae & 1 & 0 & 0 & 0 & 0 & 0 & 0 & 0 & 0 & 0 & 0 & 0 & 0 & 0 & 0 & 0 & 0 & 0 & 0 & 0 & 0 \\
\hline
\end{tabular}

* Taxa constituting the selected data set. 